\title{
An econometrics method to estimate demand of sugar
}

\author{
Negar Seyed Soleimany $^{\mathbf{a}^{*}}$ and Masoud Babakhani ${ }^{\mathrm{b}}$
}

${ }^{a}$ Department of Industrial Engineering, Iran University of Science \& Technology, Digital unit, Tehran, Iran ${ }^{b}$ Department of Industrial Engineering, Islamic Azad University, Karaj Branch, Karaj, Iran

\begin{tabular}{|c|c|}
\hline A R T I C L E I N F O & A B S T RACT \\
\hline $\begin{array}{l}\text { Article history: } \\
\text { Received June 20, } 2011 \\
\text { Received in Revised form } \\
\text { August, 16, } 2011 \\
\text { Accepted 17 August } 2011 \\
\text { Available online } \\
\text { 25 August 2011 } \\
\text { Keywords: } \\
\text { Sugar demand } \\
\text { Regression analysis } \\
\text { Sugar price } \\
\text { Price elasticity }\end{array}$ & $\begin{array}{l}\text { Sugar is one of the strategic goods in the basket of households in each country and it plays an } \\
\text { important role in supplying the required energy. On the other hand, it is one of the goods, which } \\
\text { Iranian government is about to change its subsidy strategies. To design useful sugar subsidy } \\
\text { strategies, it is necessary to know sugar position in the basket of households and be familiar } \\
\text { with households' sugar demand or consumption behavior. This research estimates sugar demand } \\
\text { for Iranian households by using time series of } 1984-2008 \text {, which is taken from central bank of } \\
\text { Iran. In this paper, first independent and dependent variables of household sugar demand } \\
\text { model are chosen based on the literature review and theory of demand. Then, sugar demand is } \\
\text { estimated by OLS technique and linear regression. The preliminary statistical observations such } \\
\text { as Durbin-Watson, F statistic and R } 2 \text { indicate that the regression is admissible. The results seem } \\
\text { plausible and consistent with theory and show that sugar demand in Iranian households is } \\
\text { associated with household expenditure, relative sugar price, family size and indicate that } \\
\text { demand of sugar is affected during the war time. The results also show the income elasticity is } \\
0.8 \text { and price elasticity is }-0.2 \text { which means sugar is essential good for Iranian households and is } \\
\text { inelastic to price. }\end{array}$ \\
\hline
\end{tabular}

\section{Introduction}

Knowledge on food demand patterns of a particular country is useful for policy planners in addressing three major policy issues. First, it helps policy planners identify which policy interventions are most appropriate in improving the nutritional status of individuals and households. Second, it is useful in designing various food subsidy strategies, which must be pursued by the government. Third, the knowledge on food demand behavior is essential for conducting macroeconomic policy analyses (Sadoulet \& de Janvry, 1995).

Given the high per capita consumption of sugar in the food basket of households in Iran, and the lack of substitute goods, it is one of the strategic goods in Iranian household's basket. Nowadays, the government of Iran is planning to make some changes in subsidy strategy for many goods where * Corresponding author. Tel: +989123003098 
sugar is one of them. Therefore, it is necessary to know about sugar demand because it can be useful for designing the best sugar subsidy strategies, which must be pursued by the government to improve household welfare.

According to demand theory, demand is the number of goods bought at a particular place and time with the current price and time. If an item in the demand is affected by its own price (P), income level $(\mathrm{Y})$, and the price of other commodities (X), and assuming a constant elasticity of demand, the demand can be exponentially mathematically expressed in terms of a demand function as Eq. (1) form (Koutsoyiannis, 1979):

$\mathrm{Q}^{\mathrm{D}}=\mathrm{a} \mathrm{P}^{\mathrm{b}} \mathrm{Y}^{\mathrm{c}} \mathrm{X}^{\mathrm{d}}$

Sugar demand has been studied in many countries. Keerthipala (2002) studied the macro policies impact on sugar sector of Serilanka. An analysis was performed to investigate the effect of changes in domestic prices of sugar, sugar import, tariff rates, interest rates and exchange rates together with mill capacities, per capita incomes and world sugar prices during the post-liberalisation period on the sugar sector of Sri Lanka. The analysis was carried out based on a simulation model, which consisted of relationships of sugarcane area, cane and sugar production and imports, consumption and price of sugar determined using data from 1978 to 1999. The results indicated that domestic price of sugar was the most influencing variable in determining sugar consumption. Price of sugar had a positive relationship with cane area and an inverse relationship with sugar consumption. The domestic price was mainly determined by the world price, which was highly volatile.

There are two kinds of sugar demand, which are industrial and nonindustrial demand. A study in United States of America (USA) indicated that total demand is more effected by nonindustrial demand and income has no significant effects on it and price elasticity was -0.16 . After introducing HFCS as a substitute goods for sugar, highly significant declining trend in sugar consumption was found (Lopez and Jorge, 1985).

Other studies on sugar demand in USA showed the price elasticity is less than unity, and sugar is an income neutral commodity in the U.S. (Gemmill, 1976; Georg \& King, 2008).

Most of the studies of food demand in Malaysia used the expenditure elasticity as the proxy for income elasticity. By doing so, some of the foods were considered as luxury goods due to more than unity expenditure elasticity. As laid down in the hypothesis of Engel's law, foods are necessary goods, thus, the income elasticity must be less than one. All of the estimated income elasticity are less than unity (Ishida et al., 2003).

A study intended to compute demand for foods in Malaysia by using the household expenditure survey 2004/2005 via the linear approximate almost ideal demand system (LA/AIDS) model. As expected, the estimated own-price elasticities for all these types of commodities follow the law of demand. The results show that the demand for sugar in response to the income is relatively positive and expenditure elasticities of sugar was 1.039 (Yeong-sheng et al., 2008).

In a paper prepared by Ramasubban, demand of sugar in Tanzania was estimated by econometrics approach using time series statistics from 1964 to 1979 . However, due to different sugar consumption pattern in the years from 1971 to 1975, the statistics for this period were removed. In this model, the independent variables included the sugar price index and income, which were fixed by 1969 index. The regression result indicated that in $1 \%$ and 5\% significant levels income, elasticity is 1.5 and price elasticity is -0.8 , which means in Tanzania sugar demand is highly affected by changing in income but is inelastic in respect to price (Ramasubban, 1983). 
In 2003, another study about food demand pattern in Tanzania was carried out, LA/AIDS system model was used and the results indicated that sugar demand is price inelastic but income elastic. The results also revealed that household income and family size had significant effects on food demand patterns (Weliwita et al., 2003).

Agricultural economic report was released by the state university of North Dakota state in 1996 contained a survey on sugar demand of many countries. In this report, first per capita sugar consumption was estimated and it was multiplied by the population and total demand was extracted. Independent variable to estimate sugar demand was the real price of sugar and GDP per capita was used instead of income. The following results were obtained from this study: In Ljrya, Indonesia, Japan, South Korea, Thailand, Australia and Europe GDP coefficient was smaller than 1 and the relationship was positive, while in Brazil, China, India, Mexico, Africa and America, this coefficient was greater than 1, just in Canada and Egypt the coefficient had inverse relationship. In addition, the price factor was significant only in some countries like, Ljrya , China, Cuba, Japan, South Korea, Thailand, Canada, Egypt, America and the relationship with sugar demand in all of them was negative (Benirschka et al., 1996).

Gemmil (1980) in his article studied sugar demand by using combined data from 73 nations gathered and using dummy variable to make appropriate estimate. The results showed that economic factors and not social factors affected the sugar demand and also indicated that price had reverse and income had direct effect on sugar demand and demand was inelastic in both.

A study was performed in Indonesia, which indicated the factors affecting on sugar demand using time series statistic during 1990-2006. The result indicated that price of coffee as complementary good, population, income had significant effect on sugar demand but sugar price, even relative sugar price was not significant. The elasticity of all the factors was less than unity, which means all of them are inelastic (Rustan, 2009).

In this paper, the main aim is to estimate sugar demand in Iranian household and income elasticity to help polices about subsidy strategy.

\section{Material and methods}

\subsection{Data sources}

The study covers the period 1984 to 2008 and the necessary data were gathered from Central Bank of Iran (CBI).

\subsection{Methodology of data analysis}

Linear regression analysis was used to estimate the sugar demand model for sugar in Iran, which was adopted from the work of Rahji and Adewumi (2008). Independent and dependent variables of household sugar demand model have been chosen according to the literature review and theory of demand and they were estimated by ordinary least square (OLS) technique. Logarithmic form is used because in most of the applied studies, it was successful model and we can directly get the elasticity.

\subsection{Variables of model}

Instead of income, expenditure was used because an Engel curve is the function describing how a consumer's expenditures on some goods or services are associated with consumer's total income. Total expenditures, is used to separate the problem of allocating total consumption to various goods from the decision of how much to save the current income (Lewbel, 2006) and also the data are collected by asking from the households and their responses about expenditure in more reliable than 
income, especially in rich families. From year 1984 to year 1989, Iran was engaged by a war and had problems of distribution system of sugar, so during those years, the price of sugar was regulated by the local government. Therefore, we consider a dummy variables for those years.

\subsubsection{Dependent variable}

$\mathrm{Q}_{\text {sugar }}=$ Total household expenditures to buy sugar (fixed by 2004 index)

\subsubsection{Independent variables}

$\mathrm{Y}_{\mathrm{t}}=$ Total expenditure of household (fixed by of 2004 index),

$\mathrm{P}_{\mathrm{t} \text { Sugar }}=$ Relative sugar price,

$\mathrm{P}_{\mathrm{t} \text { Tea }}=$ Relative tea price,

$\mathrm{P}_{\mathrm{t} \text { s.product }}=$ Relative sugar products,

$\mathrm{N}_{\mathrm{t}}=$ Family size,

$\mathrm{W}_{\mathrm{t}}=$ Virtual variable, for the war times it get 1 and for others get 0

We use Eq. (2) to compute relative price of goods:

Rlative Price of one good $=\frac{\text { one good retail price Index }}{\text { All goods retail price indec }}$

\section{Results and discussion}

We have used multi-linear regression option available in MINITAB to estimate the parameters, which are summarized as follows,

$\ln$ Qsugar $=-7.62+0.828 \ln \mathrm{Yt}+2.71 \ln \mathrm{Nt}-0.266 \ln \mathrm{Pt}$ sugar- $0.192 \mathrm{Wt}$

$\begin{array}{llll}(-1.22) & (2.71) \quad(3.65) \quad(-2.91) \quad(-1.68)\end{array}$

- $0.046 \ln$ Pt tea $-0.149 \ln$ Pt s.product

$(-0.31) \quad(-0.60)$

$\mathrm{DW}=2.20 \quad \mathrm{~F}=14.25 \quad \mathrm{R}^{2}=82.6 \% \quad \mathrm{R}^{2}(\operatorname{adj})=76.8 \%$

As we can observe from the results of the implementation of OLS technique, the regression function could estimate almost 77 percent of sugar price. However, some of the t-student results shown in parentheses for $\ln \mathrm{P}_{\mathrm{t} \text { tea }}$ and $\ln \mathrm{P}_{\mathrm{t} \text { s.product }}$ are not statistically valid when the level of significance is $5 \%$. We eliminated these two variables and the result of the implementation of OLS technique is as follows,

$$
\begin{aligned}
& \ln \text { Qsugar }=-6.87+0.809 \ln \mathrm{Yt}+2.31 \ln \mathrm{Nt}-0.265 \ln \mathrm{Pt} \text { sugar }-0.238 \mathrm{Wt} \\
& \begin{array}{llll}
(-1.54) \quad(3.60) \quad(5.72) \quad(-3.68) & (-4.05)
\end{array} \\
& \mathrm{DW}=2.09 \quad \mathrm{~F}=22.89 \quad \mathrm{R}^{2}=82.1 \% \quad \mathrm{R}^{2}(\operatorname{adj})=78.5 \%
\end{aligned}
$$

Based on the results of our regression, all coefficients represent meaningful t-students except intercept, which is not statistically meaningful. These variables can explain $78.5 \%$ fluctuations in sugar household consumption. Income elasticity is 0.8 , which means sugar is necessary good in household's basket, which is a similar result as what we have in most of the countries. The price 
elasticity is -0.265 , which indicates price inelasticity and it means changes in price make a little change in demand of sugar. The negative coefficient of virtual variable means, during the war-time, that the demand of household's sugar was reduced because of the governmental regulation. Household sugar demand has positive relationship with family size and the coefficient of $\operatorname{lnN}$ indicates that by increasing in the family size there is not any decrease in using sugar by each family member.

\section{Conclusion}

Sugar is one of the necessary goods in basket of households in Iran and demand of it is inelastic to the price and income. In this paper, we have presented an empirical analysis to measure the effects of different factors on sugar consumption for Iranian household. In our study, demand of sugar was a function of different variables such as total household expenditure, family size, sugar price and a dummy variable. We have used ordinary least square technique to estimate different components of our regression model and the results indicated that the proposed model of this paper could provide a good estimate for demand of sugar.

\section{Acknowledgment}

The authors would like to thank the anonymous referees for construction comments on this paper, which makes the final version more readable.

\section{References}

Benirschka M, W.W., Koo, \& Lou J. (1996). World Sugar Policy Simulation Model. Department of Agricultural Economics. Agricultural Experiment Station North Dakota State University, Agricultural Economics Report No. 356.

Gemmill, G. (1980). Form of function, teste and the demand for sugar in seventy-three nations. European economic review, 13(2) 189-205.

Gemmill, G. T. (1976). The World Sugar Economy: An Econo-metric Analysis of Production and Policies. Michigan State University, Agricultural Economics Report No. 313.

George, P. \& King, G. (1971). Consumer Demand for Food Commodities in the United States with Projections for 1980. University of California-Berkeley. Giannini Foundation monograph, 26, 1987.

Ishida, A., Law, S.H. \& Aita, Y. (2003). Changes in Food Consumption Expenditure in Malaysia. Agribusiness, 19 (1), 61-76.

Keerthipala, A.P. (2002). Impact of macro economic policies on the sugar sector of Serilanka. Sugar tech, 4 (3\&4), 87-96.

Koutsoyianis, A. (1979). Modern Microeconomics. London: The Macmillan Press Ltd.

Lewbel, A. (2006). Engel Curves Entry for the New Palgrave Dictionary of Economics. Boston College. $2^{\text {nd }} E d$.

Lopez, R. \& Jorge, L. (1985). Sepulveda ,Changes in the U.S. Demand for Sugar and Implications for Import Policies. NJARE, 177-182.

Rahiji, M. A. Y., \& Adewumi, M.O. (2008).Market supply response and demand for local rice in nigeria: Implications for self-sufficiency policy. Journal of Central European Agriculture, 9(3), 567-574.

Ramasubban, T.A. (1983). An Econometric analysis of consumer Demands for sugar in Tanzania. The Developing Economies, 21(2), 160-183.

Rustan, R. (2009). Study of factors affecting demand and supply of sugar in Indonesia. Journal of research in national development, 7 (2). 
Sadoulet, E. \& De Janvry A. (1995). Quantitative Development Policy Analysis. Johns Hopkins University Press.

Weliwita, A. , Nyange, D. \& Tsujii H.(2003). Food Demand Patterns in Tanzania: A Censored Regression Analysis of Microdata. Sri Lankan Journal of Agricultural Economics. 5(1), 9-23.

Wold, H. \& Juréen, L. (1953). Demand Analysis: A Study in Econometrics. John Wiley \& Sons (2 ${ }^{\text {nd }}$ Ed).

Yeong-Sheng, T., Mad Nasir, S., Zainalabidin, M., Amin Mahir A. \& Radan,A. (2008). A complete demand system of food in malaysia. The IUP Journal of Agricultural Economics, 5(3), 17-29. 